\title{
Selected Reference Books of 1977-78
}

T

HIS ARTICLE CONTINUES the semiannual series originally edited by Constance M. Winchell. Although it appears under a byline, the list is a project of the reference department of the Columbia University Libraries and notes are signed with the initials of the individual staff members. ${ }^{1}$

Since the purpose of the list is to present a selection of recent scholarly and general works of interest to reference workers in university libraries, it does not pretend to be either well balanced or comprehensive. A brief roundup of new editions of standard works, continuations, and supplements is presented at the end of the column. Code numbers (such as AA297, BD202) have been used to refer to titles in the Guide to Reference Books. ${ }^{2}$

\section{BIBLIOGRAPHY}

Munby, Alan Noel Latimer and Coral, Lenore. British Book Sale Catalogues, 1676-1800: A Union List. [London], Mansell, 1977. 146p. £12. ISBN 0-7201-07032.

A greatly expanded version of the List of Catalogues of English Book Sales 1676-1900 Now in the British Museum (London, British Museum, 1915) for the 1676-1800 period, this volume includes both auction and retail sale catalogs. The compilers searched libraries in England, Scotland, Ireland, France, Germany, and the United States for additions to the British Library holdings. The listings are arranged chronologically by the first day of sale, and indexes provide access by name of consignor, bookseller, and auctioneer. Besides the

1. Rita Keckeissen, Anita Lowry, Eileen McIlvaine, Mary Ann Miller, Doris Ann Sweet; Lehman Library: Diane Goon.

2. Eugene P. Sheehy, Guide to Reference Books (9th ed.; Chicago: American Library Assn., 1976). above information, entries include title, place of sale, a note as to whether prices were fixed and printed in the catalog (if not an auction sale), all known locations, a special designation for any copies with manuscript annotations, citations in other printed bibliographies, and reprint information.

This compilation will be of great interest to scholars concerned with eighteenthcentury England, to whom Coral's introduction suggests several specific uses of book sale catalogs in historical and literary research. A number of the sales were not limited to books, but advertised manuscripts and coins as well. Unfortunately there is no subject index to facilitate access to such entries, but one is grateful for any listing at all, considering the difficulties of locating materials in those genres. Scholars specializing in nineteenth-century England may look forward to publication of a companion bibliography which Coral is compiling for that period.-D.A.S.

\section{PUBLISHING}

The African Book World \& Press: A Directory. Répertoire du livre et de la presse en Afrique. Comp. by The African Book Publishing Record. Hans M. Zell, ed. Oxford, Zell; Detroit, Gale, [1977]. 296p. \$40. LC 76-56994. ISBN 3-7940-7014-3.

In this new directory of library and book trade information covering forty-eight African nations, the countries are listed alphabetically, with information for each arranged in eight sections. Directory information is given for all types of libraries-university, college, public, national, government-for national archives and for libraries maintained by the British Council, USIS, and the Centre Culturel Français. Then follow lists for special libraries, booksellers, trade publishers, institutional publishers, periodicals and magazines, major newspapers, 
book industry associations, and literary societies.

For many categories information is full. For libraries, for example, in addition to name, address, and telephone, the other items given are: names of chief librarian and serials librarian, size of book collection, number of serials, staff size, budget, and special subjects. For booksellers and publishers, information includes chief executive, year founded, staff size, nature of stock or list, specialization, whether overseas and blanket orders are handled, branches, foreign representatives, and affiliated companies. There is a subject index to special libraries and one for periodicals. Appendixes list book clubs and literary prizes, government printers, European and American book dealers in African books, and a bibliography on African publishing. Future editions are planned, and updating will appear in The African Book Publishing Record.R.K.

\section{LIBRARIES}

Gebhardt, Walther. Spezialbestände in deutschen Bibliotheken: Bundesrepublik Deutschland einschl. Berlin (West). Im Auftrag der Deutschen Forschungsgemeinschaft. Berlin, De Gruyter, 1977. 739p. \$65.80. LC 77-22288. ISBN 3-11005839-1.

Added title page: Special collections in German libraries: Federal Republic of Germany incl. Berlin (West).

Preface in English and German.

"The special collections in this catalogue are to be understood as products of the printing press (including printed graphics) as well as phototechnical or other methods of reproduction, collected because of their subject matter or because of their external form or by reason of their ... origin, e.g., scholars' personal libraries, monastic libraries, church and school libraries. They must also be of a certain size and be useful as source material for the researcher."-Pref.

It will be evident from the foregoing that this volume serves a very different purpose from the entries for German repositories found in Lewanski's Subject Collections in European Libraries (Guide AB97). Arrangement is by city, then by name of re- pository with a list of special collections and personal and scholars' libraries therein. A detailed index provides a subject approach and includes the names of scholars and collectors associated with specific collections. Thus the volume will be useful not only to the researcher seeking material on a specific topic, but to the scholar interested in tracking down the book collection of an individual.-E.S.

\section{ENCYCLOPEDIA}

The Harper Dictionary of Modern Thought. Alan Bullock and Oliver Stallybrass, eds. N.Y., Harper \& Row, 1977. 684p. \$20. LC 74-15814. ISBN 0-06-010576-X.

If you have ever wanted a definition of the "Annales school," or wondered what "microteaching" is, or who the "Liverpool poets" were, The Harper Dictionary of Modern Thought is your answer book. Its pages are filled with a fascinating collection of modern (roughly defined as twentiethcentury) terms and their meanings, brief evaluative discussions, and short reading lists. Scholars from all areas of the sciences, social sciences, and humanities have contributed signed entries to the volume. Entries range from technical terms, organizations, and events, to ideas, concepts, theories, fields of study, and people (though most personal name entries consist of cross-references to the movements, events, theories, etc., with which they are closely identified). Needless to say, many of the terms, especially phrases and technical terms, would not be found in a standard dictionary and, in any case, the treatment here is designed to place the terms in context more than the ordinary dictionary does. Cross-references direct the reader to related terms, and within articles all words that also appear as entries themselves are printed in small caps.

It is fun simply to browse in this compilation, and the work will be valuable both to the nonspecialist and to the specialist who ventures out of his or her own field. One caution: American users should be aware of the British orientation that shows up in the reading lists and occasionally in the substance of an article. -D.A.S. 


\section{PERIODICALS}

- Nunn, Godfrey Raymond. Southeast Asian Periodicals: An International Union List. [London], Mansell, [1977]. 456p. \$50. ISBN 0-7201-0725-3.

"With contributions from David Wyatt, Charles Bryant, Do Van Anh, Elsie Liow, the University of the Philippines Library and the University of Malaya Library."t.p.

Some 26,000 periodicals published since the beginning of the nineteenth century through 1975 have been identified and located through the Union List of Serials in the United States and Canada, New Serial Titles, Union List of Serials of the Libraries of Honolulu, and the British Union Catalogue of Periodicals, as well as catalogs of specific library collections in the United States, Western Europe, India, and, most importantly, the catalogs and checklists of libraries within the countries of Southeast Asia (Burma, Cambodia, Indonesia, Laos, Malaysia, Singapore, Brunei, the Philippines, Thailand, Vietnam). With the exception of newspapers, every type of serial, including government publications, was sought.

The listing is alphabetical within country of publication, and the standard American practice for entering periodical titles has been followed. Titles in nonroman alphabets have been transliterated. Cross-references appear, although Professor Nunn cautions that they are not introduced "as thickly as in some library catalogues." The userespecially those of us with little familiarity with the languages-should heed this warning and also keep in mind that there have been spelling reforms in certain of the countries concerned. This is a carefully compiled locational tool, and researchers are fortunate to have it. One regrets, however, that in order to keep costs down the print is in small and, in the review copy at least, rather faint type.-E.M.

Sources of Serials. 1st ed. N.Y. \& London, Bowker, [1977]. 1,547p. (A Bowker Serials Bibliography) \$52.50. LC 77-015833. ISBN 0-8352-0855-9.

"An international publisher and corporate author directory."-t.p.
Although this work will probably be most used in serials acquisitions units, it should prove helpful to reference librarians as well, providing as its does an approach from publisher or sponsoring body. Based on a name authority file developed by the Bowker Company in connection with publication of Ulrich's International Periodicals Directory, Irregular Serials and Annuals, and Ulrich's Quarterly, the first edition includes 63,000 publishers and corporate authors arranged under 181 countries, listing 90,000 current serial titles they publish or sponsor."-Pref. Within country divisions, entry is alphabetical by name of publisher or sponsoring body and includes address, copublisher, and distributor information as applicable, and a list of titles of serials published together with indication of frequency and ISSN designation as available. Publisher imprints and subsidiaries of publishing houses are interfiled as entries for publishers. Crossreferences are provided in the main body of the work, and there is an index of publishers and corporate authors.-E.S.

- Travis, Carole, and Alman, Miriam, comps. Periodicals from Africa: A Bibliography and Union List of Periodicals Published in Africa. Boston, G. K. Hall, [1977]. 619p. \$55. LC 76-53552. ISBN 0-8161-7946-8.

At head of title: "Standing Conference on Library Materials on Africa."

With the aim of providing "as comprehensive a list as possible" of African periodicals, SCOLMA has produced its most ambitious publication to date and a major reference tool for African studies: a union list that identifies and locates in some sixty university, national, government, and private United Kingdom libraries periodicals of all African countries. (Exceptions to this wide geographic coverage are South African publications not available in the British Isles and periodicals from Egypt.)

"Periodical" has been widely defined to include journals, magazines, government periodicals and annuals, noncommercial newspapers, yearbooks, and transactions and proceedings. Principal exclusions are commercial newspapers and government department reports. Publications from the earliest times to the present, including those no longer published, have been listed, 
with 1973 the cutoff date for most information. About ten African languages are represented, but the great preponderance of contents is in European languages. Arrangement is by country, with entries following alphabetically. Full bibliographical information is given when known: latest title, place, publisher, starting date, periodicity, crossreference to earlier or later titles. Locations follow (in symbol), with details of holdings when these have been supplied. Further locations are indicated by reference to BUCOP (Guide AE146) and Hewitt's Union List of Commonwealth Newspapers (Guide AF41). An index of titles makes for ease of use.

The fact that many entries give little or no information beyond a title is indicative more of the difficulties inherent in African bibliographical work generally than of shortcomings in the enormous effort that produced this valuable tool for Africanists. - R.K.

\section{DISSERTATIONS}

Krishan Gopal, comp. Theses on the Indian Sub-Continent (1877-1971): An Annotated Bibliography of Dissertations in Social Sciences and Humanities Accepted with the Universities of Australia, Canada, Great Britain and Ireland, and United States of America. Delhi, Hindustan Pub. Corp., [1977]. 462p. (Bibliographical Research Ser., 1) Rs.140. LC 77-902806.

Pollak, Oliver B., and Pollak, Karen. Theses and Dissertations on Southern Africa: An International Bibliography. Boston, G. K. Hall, [1976]. 236p. \$18. LC 75-46537. ISBN 0-8161-7863-1.

These two long, retrospective dissertation lists will be welcomed by librarians and graduate students interested in the areas covered. The first work lists more than 3,500 theses and dissertations from the English-speaking world (exclusive of the Indian subcontinent). Arrangement is in six geographic sections: Asia in general, then each of the countries or groups of countries that make up the subcontinent. Each section is subdivided in a detailed classified scheme. Entries give author, year of degree, title, and university; unfortunately, distinction is not made between doctoral and master's theses. A subject index supplements the detailed table of contents.

The 2,400 theses on the countries of Southern Africa in the Pollak compilation cover the period 1884-1974, and while nine languages and 200 institutions in thirty countries are represented, half the dissertations originate in the United States and Great Britain. Because dissertations from South Africa are well covered in other bibliographies, they are excluded here, except for those dealing with non-South African subjects. Theses are listed by broad subject headings (anthropology, geography, history, linguistics, etc.), then subdivided by the African countries covered: Angola, Botswana, Lesotho, Malawi, Mozambique, Rhodesia, South Africa, Southwest Africa-Namibia, Swaziland, Zambia, Central and Southern Africa. Under each geographic division, arrangement is chronological, then alphabetical by author. For each entry are given author, title, type of degree, university, date, and paging. There is an author index. $-R . K$.

\section{BIOGRAPHY}

Dockstader, Frederick J. Great North American Indians; Profiles in Life and Leadership. N.Y., Van Nostrand Reinhold, [1977]. 386p. il. \$16.95. LC 77-23733. ISBN 0-442-02148-8.

Designed to answer quick reference needs and to guide the reader to further sources, this compilation aims "to place a large number of major Indian figures in their proper niche in North American history."-Introd. Selection of about 300 names was made on the basis of importance to Indian culture and history rather than on the "evaluation of a career from the White point of view." Only persons of Indian ancestry appear, and no living persons are included.

Sketches, about a page in length, are arranged alphabetically; liberal use of illustrations makes for an attractive volume. A long bibliography, "For Further Reading," a "Tribal Listing," and an "Index of Names" with all their variants conclude the book. The introduction is an interesting essay on the difficulties of biographical research in Indian history and on the complexities of Indian names.- R.K. 
Watt, Donald Elmslie Robertson. A Biographical Dictionary of Scottish Graduates to A.D. 1410. Oxford, Clarendon Pr., 1977. 607p. \$66. ISBN 0-19-822447-8.

Based on the compiler's 1957 Oxford dissertation, this dictionary includes some 1,100 graduates who studied on the continent between about 1150 when "evidence for the presence in Scotland of men qualified in some way as a result of experience of higher study begins to become available" (Introd.) to about 1410 when the University of St. Andrews was founded. Watt has defined Scotland as within the present-day borders, but he has been very liberal in including people who were "in some sense Scots or who are also known to have lived and worked in Scotland."

Arrangement is alphabetical according to the standardized spelling of a name, with cross-references from variant forms. To aid the researcher who does not know the surname, there is an "Index of Christian names" referring to family name and indicating the century in which the graduate flourished. The biographical entry gives information on family, university experience, career, and, most importantly, any references to published sources of information. The dictionary shows a tremendous amount of research and also reflects pleasure in the work of compiling it.-E.M.

\section{RELIGION}

Theologische Realenzyklcpädie. In Gemeinschaft mit Horst Robert Balz [et al.], hrsg. von Gerhard Krause und Gerhard Müller. Berlin \& N.Y., W. de Gruyter, 1976- . Bd.1, Lfg.1-

(In progress) DM38 per Lfg. ISBN 3-11006944-X.

Contents: Bd. 1-2, Lfg. 3/4, AaronAnalogie.

In some respects this may be considered a successor to the Realencyklopädie für protestantische Theologie und Kirche (3d ed. 1896-1913; Guide BB21), but it is a new work, not a revision, employing a broader interpretation of "theology" and with less emphasis on the Protestant point of view. It is characterized by long, scholarly articles (most of them many pages in length) that are signed by the contributors and that include extensive bibliographies. Each volume will have its own index, and a general index is promised as the final volume of the set. The work is to be in twenty-five volumes of about 800 pages (five Lieferungen) each; the publishing schedule calls for publication of six Lieferungen per year.-E.S.

\section{LITERATURE}

Bonnefoy, Claude; Cartano, Tony; and Oster, Daniel. Dictionnaire de littérature française contemporaine. Paris, Delarge, [1977]. 411p. il. ISBN 2-7113-0077-3.

Although this is basically a dictionary of authors, emphasis is very much on the literature rather than on biographical detail. It treats some 200 carefully selected writers of French literature (including a few Canadians, Belgians, etc.) who were alive as of January 1, 1976, and who, among older writers, had continued to publish new works in their late years. In most instances, the biographical information is very brief (sometimes minimal) and the bulk of the entry is devoted to commentary on the writer's works, themes, ideas, and his or her place in the contemporary literary scene. This is, one might say, a book for reading almost as much as for reference. A bibliography follows each author entry, but this is usually limited to a list of the writer's own works and only occasionally are works about an author cited. Appendixes deal briefly with literary movements and genres, regional developments in the field of French literature, and literary magazines. - E.S.

Hatch, James Vernon, and OMANii, Abdullah. Black Playwrights, 1823-1977: An Annotated Bibliography of Plays. N.Y., Bowker, 1977. 319p. \$17.50. LC 7711890. ISBN 0-8352-1032-4.

Seeking to provide a comprehensive and reliable record of plays by black American authors, the compilers of this bibliography have drawn upon a considerable body of printed sources and library collections, including the Hatch-Billops Archives and the Schomburg Center for Research in Black Culture of the New York Public Library. The bibliography lists over 2,700 plays by approximately 900 Afro-Americans; not only such well-known authors as Lorraine 
Hansberry and Langston Hughes are represented, but also many less-familiar names such as William Duncan (Three Showers, 1920) and Jaso Wati (Lazarus, 1977). Some Caribbean and other black nationals are listed if their plays have been produced in the United States; also, the policy of inclusion concerning plays has been extended to some film, television, and radio scripts.

In addition to author and title, the entry for each play may include some or all of the following items: date, genre, description (theme or plot), cast (number, race, and sex), length (acts or scenes), production (place and date), publication (in a book or periodical), library source, and permission (author or agent). There is an index of play titles, including alternate titles. The volume is completed by selected bibliographies of sources on black drama (books, anthologies of plays, dissertations, and theses) and by three appendixes: (1) taped interviews in the Oral History Library of the HatchBillops Archives; (2) awards to black theater artists; (3) addresses of authors and agents. - A.L.

Lever, Maurice. La fiction narrative en prose au XVIIème siecle: répertoire bibliographique du genre romanesque en France (1600-1700). Paris, Éditions du Centre National de la Recherche Scientifique, 1976. 645p. 160FF. ISBN 2-22201875-7.

At head of title: "Centre d'Étude de la Littérature Française du XVIIème et du XVIIIème Siècle (Paris-Sorbonne)."

It is not often that new reference works from two different publishers dovetail in the way that Lever's bibliography of seventeenth-century French prose fiction does with the Bibliographie du genre romanesque français, $1751-1800$ by Angus Martin and others, which was noted in this column in January 1978, the one providing a predecessor, the other a successor to S. P. Jones' List of French Prose Fiction from 1700 to 1750 (Guide BD778).

Interpreting "narrative fiction" as broadly as possible, Lever aims to transcend the limitations of R. C. Williams' Bibliography of the Seventeenth-century Novel in France and to overcome the errors and deficiencies of R. W. Baldner's revision of that work
(Guide BD776). The main listing is by title; and full bibliographic information, library locations, attribution of anonymous works, references to later editions, and the "incipit" of each work are given in that section. An author list (including pseudonyms) provides the alternate approach. $-E$.S.

\section{FOLKLORE}

Flanagan, Cathleen C., and Flanagan, John T. American Folklore: A Bibliography, 1950-1974. Metuchen, N.J., Scarecrow Pr., 1977. 406p. \$16. LC 77-23381. ISBN 0-8108-1073-5.

This is an effort to provide a record of twenty-five years' publishing of collections of and writings about American verbal folklore. (The bibliography excludes "material folklore" such as folk art and architecture, weaving, quilting, etc.) It supplements Charles Haywood's Bibliography of North American Folklore and Folksong (1951; Guide CF24), most importantly in the realms of criticism, history, and theory. The selective and selectively annotated entries are arranged by type: ballads and songs, tales and narratives, legends, myth, beliefs, customs, cures, heroes, folklore in literature, proverbs, riddles, names, cries, and other miscellaneous types; the groupings are preceded by sections for bibliography, study and teaching, and general folklore.

But how will users find an Appalachian ballad, a protest song, a Colonial ballad, an Indian myth, an Afro-American cowboy song, an Army joke, or articles about them? Unless they know the author's name, they will need to scan the pertinent section, for there are no subject, regional, or ethnic indexes. And one must be astute in choosing where to scan, for each item is listed only once. Even with this major detraction, the bibliography should save the folklorist considerable time and possible oversight. M.A.M.

\section{SOCIOLOGY}

Brickman, William W. The Jewish Community in America: An Annotated and Classified Bibliographical Guide. N.Y., Burt Franklin, 1977. 396p. (Ethnic Bib- 
liographical Guides, no.2) \$19.95. LC 76-30284. ISBN 0-89102-057-8.

An excellent introductory essay traces the major phases of American Jewish life from Colonial times to the present and adds eloquence to the stated intent of this bibliography: to further substantial study of the American ethnic heritage by providing authentic data and avoiding ethnocentrism.

Works in English, Hebrew, Yiddish, Ladino, German, French, Hungarian, Polish, and Russian and ranging from scholarly papers to general histories useful as junior high textbooks are entered with careful evaluative annotations and classified by subject or type of document. Categories include regional and local history, specialized historical works (American diplomatic action affecting Jews, Jewish farmers, early American Jews, etc.), sources and collections of documents, social and communal life, political and economic activity, intergroup relations, and bibliographies. Appended is a selection of letters and statements dated from 1655 to 1918 , showing examples of the Jewish people's petitions to American institutions and leaders having power over their well-being. There is a main entry index. $-M$.A.M.

Krichmar, Albert. The Women's Movement in the Seventies: An International English-Language Bibliography. Metuchen, N.J., Scarecrow Pr., 1977. 875p. \$30. LC 77-21416. ISBN 0 8108-1063-8.

Here is another extensive bibliography that should serve the field of women's studies well. It can supplement the many specialized bibliographies that now abound, and because of its international scope and wide subject coverage it can facilitate comparative and cross-cultural research (serving perhaps as a companion to Sue-Ellen Jacob's 1974 publication, Women in Perspective: A Guide for Cross-cultural Studies).

This is an issue-oriented work that includes studies published between 1970 and 1976 , but reaches from Biblical times to the present. Besides listing books, articles, and reference works, special effort was made to include review essays. Arrangement is by continent, subdivided by country, plus an "international" category; within each geographical area there are eight broad categories: cultural and literary, economic, educational, legal and political, psychological, religious and philosophical, scientific and technological, and social and anthropological.

The country having by far the largest number of entries is the United States (65 percent of the total), and the most inclusive category is sociology, which covers such issues as rape, sexist language, woman's image in the media, lesbianism, health care, etc., as well as the general sociological concerns of status, division of labor, and employment. A carefully detailed index provides full access to the material, and there is also an author index. Descriptive annotations are provided on a selective basis. M.A.M

\section{POLITICAL SCIENCE}

Heggie, Grace F. Canadian Political Parties 1867-1968: A Historical Bibliography. Toronto, Macmillan, 1977. 603p. $\$ 75$. (Can.) ISBN 0-7705-1341-7.

The student of Canadian political history whose library can afford this book has cause to rejoice, for between its covers is a nearly comprehensive record of the secondary sources-the "objective" reporting as well as the scholarly writing - that further historical research and present "a contemporary record ... of the political literature of post Confederation Canada."-Pref. The 8,850 items include books; essays in collections; Canadian historical and political societies' publications; theses from Canadian, American, and British universities; and articles appearing in scholarly journals and in a selection of general periodicals. Nineteen seventy is the publication cutoff date, except for articles, which are represented only through 1969. Not included are periodicals representing specific groups or interests (with certain exceptions), newspapers, manuscripts, political party publications, and unsigned articles. Nor are government publications systematically included.

Besides examining every item and providing annotations whenever clarification seemed desirable, Heggie has sought to impose form upon the considerable substance of her work: she employs a structure designed "to allow a natural flow and a candid 
reflection of the works contained in each section." This is accomplished by a chronological/topical arrangement that divides the major part of the bibliography, "The Federal and Political Parties of Canada," into four periods of political history, with subdivisions that follow chronologically the dominant historical and political events. There is also a section on the individual political parties, again chronologically arranged. The second part of the bibliography, "Government and Political Institutions," is not chronological. To help the user locate arbitrarily placed items whose categorization is open to interpretation, there is an excellent subject index, and a useful note shows the changes in official titles of the political parties through time. Finally, too good not to mention, there are the appendixes: a guide to sources and a descriptive list of periodicals examined. Each part of this work seems as excellent as the whole.-M.A.M.

\section{United States Political Science Documents.} v.1- , 1975- . Pittsburgh, Univ. of Pittsburgh, University Center for International Studies in conjunction with the American Political Science Association, 1976- Annual. (Price varies: v.3, 1977, pts.1-2, \$120.)

This abstracting service is one of the results of the cooperative program initiated in 1970-71 by the American Political Science Association and the University of Pittsburgh to develop a comprehensive information system for political scientists, utilizing a bibliographic data base. A "terminology control device" (the Political Science Thesaurus, ed. by Carl Beck et al., Wash., Amer. Pol. Sci. Assoc., 1975) was developed first as an access tool to the data base, and in 1976 the first volume of USPSD was published. The data base used in its production is also utilized for a number of spin-offs, or "derivative publications," such as Comparative Studies Documents, Ethnic Studies Bibliography, and Asian Studies Bibliography.

The second volume (1976) of USPSD provides 2,824 "document descriptions" (abstracts) of articles in 124 American periodicals dealing with political, social, and policy studies and is published in two physical volumes. Part 1 (1,25lp.) includes five indexes: Author/Contributor, Subject, Geographic Area, Proper Name, and Journal. Terms used in the subject and geographic area indexes are derived from the Political Science Thesaurus, and there is a "Rotated subject descriptor display" that lists subject descriptors under each of their key words, indicating their relative position in the alphabetical order. All index entries give complete bibliographic information for each item as well as the accession number for its "document description." Part 2, "Document descriptions” (861p.), provides for each item: author, title, journal reference, abstract of 100-200 words, and key subject descriptors; when appropriate, it also includes key geographic areas, proper names, special features (list of titles of tables, charts, figures, and maps), and names of persons cited.

USPSD's claim to provide "unique items of information [lists of special features and names of cited persons] and vocabulary control not found in current awareness services" (Introd.) is largely justified. The publishers have taken pains with the Thesaurus, are planning a revision thereof, and are evaluating USPSD for possible refinements of the subject index. However, the index that needs the most revision is the Proper Name index. It has become a catchall for terms not included in the thesaurus (e.g., "divorce"). Articles on "sub-national" geographic areas (cities, states, provinces, regions, etc.) are indexed here rather than in the geographic area index. In the 1976 volume there are entries for "Department of State (US)," "Department of State (United States)," and "State Department (US)"; and there are three sections of "Russia (PreRevolutionary)" entries interspersed with entries for "Russia (Pre-Soviet)," "Russia (Pre-Communist)," and "Russia (Pre-18th century)" in an arrangement whose logic escapes this reviewer.

For those of us accustomed to working with subject headings developed by librarians for librarians, a subject index based on the concepts and language of political scientists may take some getting used to. But librarians will find that USPSD pays quick rewards when a reader needs information on consociational democracy, linkage politics, NIEO or Ujamaa villages (all entries 
from the subject and proper name indexes). It is one of those rare tools that is exciting to use; it is handsomely produced; and it is well worth its price as well as the time librarians and other users will spend just browsing through it. - D.G.

\section{HISTORY \& AREA STUDIES}

The Modern Encyclopedia of Russian and Soviet History. Ed. by Joseph Wieczynski. Gulf Breeze, Fla., Academic International Pr., 1976-78. v.1-6. (In progress) $\$ 27.50$ per $v$. LC $75-11091$. ISBN 0-87569-064-5.

From "Aachen, Conference of" to "Chernogai Uprising of 1861," the first six volumes of this encyclopedia (projected to be in forty to fifty volumes) bring together a great deal of information on the people, places, events, institutions, and ideas of Russian and Soviet history. It aims for comprehensiveness in the field of history and includes, as well, entries for writers, scientists, and others "whose activities were of some impact upon society at large" (p.vii), and for geographical names "when specific events connected with them are themselves important to Russian history." Living people are not included, nor are specialized topics concerning archives and research tools and resources.

Presented in English, the articles come from a variety of sources and vary in style and detail; many are translations from the "Soviet Historical Encyclopedia" (Sovetskaia istoricheskaia entsiklopediia. 1961-76. 16v.), the Bol'shaia encyclopedia (Guide AC72), the Brockhaus-Efron encyclopedia (Guide AC76), and other Russian sources, while others have been "culled from standard monographs, research articles and similar writings" ( $p . v)$. In addition, a number of articles have been written especially for this encyclopedia by American, Canadian, and British scholars. (Only articles in the latter category and those from the "Soviet Historical Encyclopedia” are attributed.) Many entries include bibliographies listing Russian and, where possible, English sources.

The value of the work for students who do not read Russian is obvious, but even specialists in the field may find information here that is not readily available in other reference sources (e.g., the historiographical article on the historian Mikhail Bogoslovskii by Richard Hellie). One hopes that the set will include a good index as the final volume. Also, one wishes that the volumes were marked with greater specificity on the spines rather than the "Aa-An," "An-Ba," "Ba-Be," etc., used thus far.-A.L.

The Reader's Encyclopedia of the American West. Ed. by Howard R. Lamar. N.Y., Thomas Y. Crowell Co., [1977]. 1,306p. $\$ 24.95$. LC 76-17236. ISBN 0-69000008-1.

One feels that the compiler enjoyed assembling this dictionary, for it is a pleasure to read. The articles, which are signed, are well written and have short bibliographies (in some cases a bit dated); the pictures are judiciously selected and clearly produced; and the choice of subjects seems well balanced between the contemporary and the historical, the fictional and the nonfictional. The work tries to answer the needs of all types of users, whether literary, historical, biographical, religious, ethnic, political, economic, or scientific. Thus the "American West" is defined as "any part of the continental U.S. in its formative or frontier period [as well as] the entire trans-Mississippi West from the time of first exploration to the present."-Pref. Canada is treated insofar as it overlaps with the U.S.; e.g., in entries for "Indians of the Northwest Coast," “Canadian-American problems," or "Frontier, Canada."

The only real difficulty in using the work is in finding the appropriate entry. Crossreferences appear, but not as frequently as necessary in a work without an index; nor is there a classified listing of article titles. For example, a lengthy article on "Diseases" has a cross-reference to "Doctors" but not to the entry "Indian and white diseases."

To illustrate the great range of articles included and the difficulty in locating information, the reviewer set this problem: What information is provided on the influence of the West on the world outside the U.S.A.? "Films, Western" includes a paragraph on European-made Westerns; Puccini's Girl of the Golden West is mentioned in "Music about the West"; an Italian touring opera company is mentioned under "Opera"; the 
Indian as idealized by Europeans in "Noble savage concept." But there is no entry for travelers' accounts, although there are entries for "Tourist travel," "Emigrants' guidebooks," and "Indian captivity novels"; nothing about the craze for denim, cowboy boots, etc., appears in the entry "Cowboy clothing"; nothing about Karl May (who is still picturing the West for German readers and has recently been translated into English) in the articles "Novel, Western," or "Dime Novels," or "Grey, Zane." It is a shame that the effectiveness of this very useful reference book is reduced through lack of an index.-E.M.

\section{NEW EdTTIONS, SUPPLEMENTS, ETC.}

About 150 bibliographies published since 1970 are included in Reuben Musiker's "Supplement 1970-1976" (Johannesburg, The Library, Univ. of the Witwatersrand, 1977. 34p.) to his South African Bibliography (1970; Guide AA72). It supersedes the earlier supplement published in 1975 .

With the publication of volume 28 covering "Voy-Z" (Barcelona, Antonio Palau Dulcet, 1977), the main portion of the second edition of Palau y Dulcet's monumental Manual del librero hispanoamericano (Guide AA885) is completed. Plans call for publication of an "índice de títulosmaterias" within about two years' time and a supplement (with additions and corrections) by 1982 .

Kenneth F. Kister's Dictionary Buying Guide; A Consumer Guide to General English-language Wordbooks in Print (N.Y., Bowker, 1977. 358p. $\$ 15.95$ ) is a successor to S. P. Walsh's English Language Dictionaries in Print, last issued in 1969 as part of the volume Home Reference Books in Print (Guide AA405). Intended for the person who is contemplating purchase of a dictionary, the guide reviews at some length fifty-eight general adult English-language dictionaries and evaluates more briefly some sixty school and children's dictionaries. In addition, it offers concise coverage of about 225 "special-purpose dictionaries and wordbooks" (dictionaries of etymology, slang, synonyms, idioms, and usage; style manuals; secretary's handbooks; etc.).

Raise the flag! Volume 1, covering A-B, of the Bibliothèque Nationale's Catalogue collectif des périodiques du début du XVIIème siècle à 1939 has now appeared (Paris, Bibliothèque Nationale, 1977. 1,055 p.). Inasmuch as the set has been published in reverse order beginning with volume 4 in 1967 (see Guide AE142), it means that the main portion of this union list of serials in French libraries is at last complete. Because the work is a title listing (there are some 310 pages under "Bulletin"), a fifth volume providing an index of societies and other issuing bodies will be published as the final volume of the set.

Although revisions have been made in the earlier sections of Debrett's Correct Form edited by Patrick Montague-Smith (1970 ed. Guide AK74), the most obvious change to be noted in the new edition (London, Debrett's, 1976. 423p. 55.95 ) is the addition of new sections for "American usage" and "Usage in other foreign countries."

Another computer-produced Bible concordance has recently appeared. Prepared under the general editorship of Stephen J. Hartdegen, O.F.M., Nelson's Complete Concordance of the New American Bible (Nashville, Thomas Nelson, Inc., 1977. $1,274$ p. $\$ 34.95)$ offers some 300,000 entries under 18,000 keywords. Although printed in small type on a three-column page, the use of boldface capitals for keyword headings, italic letters to signal position of the keyword within quotations, and good spacing make for a legible text.

The "Fourth Supplement, 1971-1975" (London, Mansell, 1977. 429p. £20) to the Index Islamicus (Guide BB343) represents the first quinquennial cumulation since the bibliography began to appear on an annual basis. It combines the listings from the yearly issues for the period and adds some items noted since those issues were published.

Helen H. Palmer's European Drama Criticism, 1900-1975 (2d ed. Hamden, Conn., Shoe String Pr., 1977. 653p. \$25) cumulates the entries from the first edition and its two supplements (compiled with A. J. Dyson; Guide BD182) and adds new critical material published through 1975.

Compiled under the editorship of John Albert Robbins, the second edition of American Literary Manuscripts (Athens, 
Univ. of Georgia Pr., 1977. 387p. \$16) follows the basic format of the 1960 edition (Guide BD284), "adding a few new symbol categories and devising alternate modes of reporting to gain more flexibility."-Introd. The author list was expanded from 2,350 names to nearly 2,800 , and the number of libraries covered from 273 to 600 . There is a separate list of "Authors for whom no holdings were reported."

Revised, reset, and employing new illustrations, the sixth edition of Leslie Halliwell's Filmgoer's Companion (N.Y., Hill \& Wang, 1977. 825p. \$30; for $3 \mathrm{~d}$ ed. see Guide BG140) adds about a thousand new entries. In addition, many of the existing entries were extended or revised.

Friedrich Domay's Handbuch der deutschen Wissenschaftlichen Akademien und Gesellschaften (Wiesbaden, F. Steiner Verlag, 1977. 1,209p. DM240) represents a new and greatly expanded edition of the compiler's Handbuch der deutschen wissenschaftlichen Gesellschaften (1964; Guide CA77). In addition to added information for scientific academies as indicated in the title, there are new sections for information science and documentation and for the arts.

Revised under the editorship of Kenneth T. Jackson, the new edition of the Atlas of American History (N.Y., Scribner's, 1978. $294 \mathrm{p}$. \$40) retains all 147 of the maps in the original edition edited by James Truslow
Adams (1943; Guide DB100) and adds 51 new ones. "Most of the new maps deal with twentieth-century developments or with other subjects that were considered only slightly or not at all by Adams and his coworkers."-Introd.

Yet another addition to the growing number of guides to British manuscript collections is the Guide to the Manuscripts in the National Maritime Museum. Volume 1, "The Personal Collections," edited by R. J. B. Knight (London, Mansell, 1977. 234p. f12.50) lists and briefly describes the collections of papers of some 300 people associated with the Royal Navy and the merchant shipping industry. A brief biography emphasizing the period covered by the material on file precedes the description of each collection of papers. There are general, chronological, and ship indexes. A second volume will describe other manuscript holdings of the museum.

The Library of Congress has prepared a cumulation of the indexes to volumes 1-7 of the Antarctic Bibliography (Wash., for sale by Supt. of Docs., 1977. 783p. \$12). As in the original volumes (see Guide $\mathrm{DH} 1$ ) there are four separate sections: (1) author index, (2) subject index, (3) geographic index, and (4) a grantee index to those publications listed in the bibliography that resulted from work undertaken with National Science Foundation support.-E.S. 


\section{NEW Up-To-Date Books From Noyes Data}

NOYES DATA has developed two new techniques of vital importance to those who wish to keep abreast of rapid changes in technology and business conditions: 1) our advanced publishing systems permit us to produce durably-bound books within a few months of manuscript acceptance; 2) our modern processing plant ships all orders on the day after they are received.

\section{HARDCOVER BOOKS-SUMMER 1978}

VINYL CHLORIDE AND PVC MANUFACTURE-PROCESSES AND ENVIRONMENTAL ASPECTS by M. Sittig: Vinyl chloride monomer (VCM) is a notorious example of one chemical presenting a serious challenge to air pollution control. In this book major production processes for VCM and polyvinyl chloride (PVC) are described, indicating where VCM emissions are generated and how they can be controlled. ISBN 0-8155-0707-0; \$45

COSMETICS, TOILETRIES AND HEALTH CARE PRODUCTS-RECENT DEVELOP. MENTS by G.W. Owens: Today's cosmetics are considerably milder, less greasy and much less toxic than they were even five years ago. Because of the superior performance of the new ingredients, formulations are simpler, helping to cope more easily with costs and labeling requirements. 220 processes. ISBN 0-8155-0708-9; \$36

FUEL ADDITIVES FOR INTERNAL COMBUSTION ENGINES-RECENT DEVELOP. MENTS by M.W. Ranney: This book, presenting over 200 processes and hundreds of formulated fuel additive compositions, provides a comprehensive picture of technological achievements in this field. Effective additives, which really increase mileage, will provide many new business opportunities. ISBN 0-8155-0709-7; \$39

FOOD PACKAGING by N.D. Pintauro: Boil-in-bags and retort pouches are just examples illustrative of how plastic films, rigid plastics and metal foil are replacing paper materials, glass and metal cans. This book reviews and summarizes designs and functional aspects of representative package systems for the various food groups and beverages as well as for multicomponent containers. ISBN 0-8155-0710-0; \$39

NITROGEN CONTROL AND PHOSPHORUS REMOVAL IN SEWAGE TREATMENT edited by D.J. De Renzo: Discusses control and removal methods that have been found effective and practical in sewage treatment plants. The information, based on federally funded studies, is of immediate value to city planners, regulatory agencies, and treatment plant operators. ISBN 0-8155-0711-9; \$32

COAL DESULFURIZATION PRIOR TO COMBUSTION edited by R.C. Eliot: Coal cleaning, and especially removal of pyritic sulfur before burning, appears to be an attractive alternative to post-combustion treatment of effluent gases. This book is an accurate state-of-the-art report and practical manual for solving present-day problems of burning coal. ISBN 0-8155-0712-7; \$42

ADHESIVE AND SEALANT COMPOUNDS AND THEIR FORMULATIONS bY E.W. Flick: Here are presented over 500 adhesive and related formulations of the latest types. No lead-containing raw materials and hardly any organic solvents are being used. This will be appreciated by U.S. manufacturers and others who must concern themselves with EPA and OSHA regulations. ISBN 0-8155-0713-5; \$36 